\title{
Evaluation and Importance of Our Newborn Hearing Screening Results
}

\section{Yenidoğan Işsitme Tarama Sonuçlarımızın Değerlendirilmesi ve Önemi}

\author{
Alaaddin Yorulmaz, Umut Genç* ${ }^{*}$ Fatma Hilal Yılmaz, Semra Küçüksümbül* \\ Beyhekim State Hospital, Clinic of Child Health and Diseases, Konya, Turkey \\ *Beyhekim State Hospital, Clinic of Otorhinolaryngology, Konya, Turkey
}

\section{Abstract}

Aim: In this study, we aimed to share the hearing screening results of newborns born in Konya Beyhekim Hospital and the risk factors in infants with hearing loss in the light of the current literature.

Methods: In this study, the results of 13693 newborns who underwent hearing screening in our hospital between January 2011 and April 2016 were retrospectively evaluated. The hearing screening was performed by transient evoked otoacoustic emissions (TEOAEs). Auditory brainstem response (ABR) screening test was made in babies who failed the TEOAE test twice. The patients' sociodemographic and clinical characteristics and risk factors were evaluated.

Results: 10987 (80.2\%) of 13693 newborns who underwent hearing screening have passed on the first TEOAE screening. 863 (38.5\%) newborns have passed on the second TEOAE screening. 1134 (93.3\%) newborns have passed on the ABR screening. 62 of 81 (0.6\%) patients who have failed the ABR screening had no hearing loss. Thirteen of the newborns born in our hospital had hearing loss.

Conclusion: As in many centers in our country, newborn hearing screening has become routine in our hospital. It is important to follow up newborns for determining the actual incidence and early diagnosis and treatment of hearing loss.

Keywords: Newborn, hearing screening, otoacoustic emission

\section{Introduction}

Hearing loss is one of the most common congenital anomalies. It has been reported that hearing loss $\geq 30$ $d B$ occurred in 1-6 per 1000 newborns $(1,2)$. This rate is known to be higher in babies treated in newborn intensive care units (3). In babies, auditory warning in the first year of life is very important for language
Amaç: Bu çalışmada, Konya Beyhekim Devlet Hastanesi'nde doğmuş tüm yenidoğanların işitme tarama sonuçlarını ve işitme kaybı olan bebeklerin risk faktörlerini güncel literatür eşliğinde paylaşmayı amaçladık.

Yöntemler: Bu çalışmada, Ocak 2011-Nisan 2016 tarihleri arasında hastanemizde yenidoğan işitme tarama testi yapılan 13693 yenidoğan bebeğin sonuçları retrospektif olarak incelendi. İşitme tarama testi Geçici Uyarılmış Otoakustik Emisyonlar (TEOAE) yöntemi ile yapıldı. İkinci kez TEOAE testini geçemeyen bebeklere İşitsel Beyinsapı Cevabı $(A B R)$ tarama testi ölçümleri yapıldı. Hastaların sosyodemografik, klinik özellikleri ve risk etmenleri değerlendirildi.

Bulgular: İşitme tarama testi yapılan 13693 yenidoğan bebeğin 10987'si $(\% 80,2)$ birinci TEOAE tarama testinden geçmiştir. iki bin iki yüz kırk $(\% 16,3)$ yenidoğan bebeğe ikinci TEOAE tarama testi yapıldı ve $863(\% 38,5)$ yenidoğan ikinci TEOAE testinden geçti. Bin yüz otuz dört $(\% 93,3)$ yenidoğan bebek ABR testinden geçti. ABR tarama testinden geçemeyen $81(\% 0,6)$ hastanın 62'sinde işitme kaybı olmadığı öğrenildi. Hastanemizde doğan bebeklerin 13'ünde işitme kaybı tesbit edildi.

Sonuç: Ülkemizde birçok merkezde olduğu gibi, hastanemizde de yenidoğan işitme taraması rutin hale getirilmiş olup, işitme kaybının gerçek insidansının belirlenmesinde, erken tanı ve tedavisinde tedavide yenidoğanların takibi önemlidir.

Anahtar Sözcükler: Yenidoğan, işitme tarama, otoakustik emisyon
Address for Correspondence/Yazışma Adresi: Alaaddin Yorulmaz Beyhekim State Hospital, Clinic of Child Health and Diseases, Konya, Turkey Phone: +90 2242243060 E-mail: dralaaddiny@gmail.com

Received/Geliş Tarihi: 11 October 2016 Accepted/Kabul Tarihi: 29 October 2016 development and cognitive functions (4). The sense of hearing must be within the normal limits from the birth in terms of language acquisition and language skills and environmental compliance, communications, intelligence and psychosocial development $(5,6)$. In a study by Giordano et al. (7) performed in 2015, it was observed that academic performance, language and cognitive skills, 
behavioral development, environmental compliance, and peer communication of children who were diagnosed with hearing loss in the early period were within the normal limits. Since children with hearing loss do not take the necessary stimuli from the external environment, they do not show enough mental development and fail in education and social life. Early recognition of hearing loss prevents disabilities and impairments. The development of the individual can become nearly normal with early diagnosis and treatment of hearing loss.

Hearing screening should be done for early diagnosis and treatment of hearing loss in infants. Therefore, hearing screening programs have been started all over the world for early diagnosis. The diagnosis of hearing loss in a baby who has failed a screening program is made in the 12-36 months of life. Hearing loss screening in newborns detects the half of the cases with hearing loss (8). It can be delayed to three years to confirm the diagnosis in children who did not undergo hearing loss screening at birth (9). As a result of newborn hearing screening, the time of diagnosis of hearing loss was reduced to 3.5 months (10).

In newborn hearing screening around the world, threestep screening protocol is commonly applied with evoked otoacoustic emissions (EOAE) and auditory brainstem response $(A B R)$ test $(2,11)$. There are two types of EOAE today: transient EOAE (TEOAE) and distortion product otoacoustic emissions (DPOAE). Although both tests are used with success in newborn hearing screening, the TEOAE is technically simpler and reveals even very mild hearing loss compared to DPOAE and, thus, it is more preferred.

In this study, we aimed to share the hearing screening results of newborns included in our study and the risk factors in infants with hearing loss in the light of the current literature.

\section{Methods}

In this study, the results of 13693 newborns who underwent hearing screening in our hospital between January 2011 and April 2016 were retrospectively evaluated. Hearing screening in babies born in our hospital were performed in the newborn hearing screening unit before being discharged from the hospital. The hearing screening in babies referred from the near hospitals were performed in the same unit at the hospital admission. The hearing screening was performed in a quiet room by experienced audiometrists while the baby was asleep or calm and was on mother's lap in a dormant state. Both ears were tested during the test. The Echo-Screen device was used for TEOAE measurements in Konya Beyhekim Hospital. The probes were selected according to the size of the external auditory canal of the baby. In the measurements made in both ears by TEOAE, the occurrence of response in 3 of 4 band measurements between $1 \mathrm{kHz}$ and $4 \mathrm{kHz}$ was interpreted as that the infant has 'passed' the test. Taking two or fewer responses in one or both ears was interpreted as that the infant has 'failed' the test and these babies were recalled for control 14 days later. The patients were examined by an ear, nose and throat (ENT) specialist in terms of cerumen, otitis media, effusion and ear anomalies before the test. As a result of the examination, if there were issues related to the external ear canal and the middle ear that may affect the response to the TEOAE test, the necessary treatment and recommendations were given. The ABR test was performed for babies who have failed the second TEOAE. The result of the ABR test was automatically given as passed or failed. Babies who have failed the ABR screening were referred to a senior center. The screening results were given to families in writing. The screening findings of the babies were recorded in a hearing follow-up record form. Patients' sociodemographic and clinical characteristics and risk factors were evaluated. $A B R$ screening was not performed since the necessary equipment was not available in the newborn hearing screening unit at our hospital in 2011 and newborns who have failed the second TEOAE screening were referred to a tertiary care center.

After the ENT examination, the impedancemetric examination, tympanogram, acoustic reflexes, clinical brainstem evoked response audiometry, TEOAE, auditory steady-state response and, if necessary, cochlear microphonic assessment are performed again for babies referred to the tertiary care center, the diagnosis is established by determining the presence and degree of hearing loss. Instrumentation procedure and training program are initiated by making behavioral testing in the free area for the babies diagnosed with hearing loss. If type and degree of hearing loss in infants are appropriate, they are followed up in terms of cochlear implants.

The records of our patients who were referred to the tertiary care center were analyzed. The information about the patients whose records could not be reached was achieved through contact information. Families of the babies applied for newborn hearing screening were asked to fill out a form which questions the risk factors for neonatal hearing loss. They were determined by taking into account the risk criteria defined by the Joint Committee on Infant Hearing-1994 (12). The study was approved by the Ethics Committee of Selçuk University. Ethics committee approval was received for this study from the Local Ethics Committee (approve number: CMRC2016/244).

\section{Results}

13693 newborns who were born in our hospital and referred from the nearby hospitals between January 2011 
and April 2016 underwent hearing screening. The number of newborns included in hearing screening during 6 years and the distribution of the test results according to the years are summarized in Table 1. 10987 (80.2\%) newborns who underwent hearing screening have passed on the first TEOAE screening test. The ENT examination and the second TEOAE screening test were recommended to be made 14 days later for 2706 (19.8\%) babies who have failed the first TEOAE. 2240 (16.3\%) newborns underwent the second TEOAE screening test. Four hundred and sixtysix $(17.2 \%)$ babies have not been brought for control. Eight hundred and sixty-three (38.5\%) newborns have passed on the second TEOAE. 1377 (61.5\%) newborns have failed the hearing screening test. The ABR screening was planned to be performed 1 week later for 1377 $(61.5 \%)$ newborns who have failed the hearing screening test. 1215 patients underwent the ABR screening test. One hundred forty-two (10.3\%) patients have not been brought for control. 1134 (93.3\%) newborns have passed on ABR. Eighty one $(0.6 \%)$ patients who have failed the $A B R$ screening test were referred to a tertiary care center. The information about the status of the babies who were referred to the tertiary care center is shown in Table 2.
Parents of six (7.4\%) of 81 newborns who were referred to the tertiary care center could not be reached despite repeated calls. The general characteristics of the babies who were referred to the tertiary care center is summarized in Table 3 . When the referred patients were evaluated in detail, it was learned that 62 patients had no hearing loss as a result of repeated follow-up. As a result of our study, $13(0.94 / 1000)$ of the newborns born in our hospital had hearing loss. Nine $(0.06 \%)$ of these patients had a bilateral hearing loss and four $(0.02 \%)$ had unilateral hearing loss. It was learned that four patients with hearing loss underwent cochlear implants in another center. It was learned that nine patients have used hearing aid and also cochlear implant surgery was decided.

The risk factors in 13 patients with hearing loss who were referred to the tertiary care center from our hospital were tried to be determined. According to the information obtained, one patient was born prematurely, two had low birth weight, two patients had family history of hearing loss, one received phototherapy due to high bilirubin levels, four stayed in the newborn intensive care unit due to infection and three patients used ototoxic drugs for more than three days.

\begin{tabular}{|c|c|c|c|c|c|c|c|c|}
\hline \multirow{2}{*}{ Year } & \multirow[t]{2}{*}{ Number of scanned baby } & & \multicolumn{2}{|c|}{ 1. TEOAE } & \multicolumn{2}{|c|}{ 2. TEOAE } & \multicolumn{2}{|l|}{ ABR } \\
\hline & & & $\mathbf{n}$ & $\%$ & $\mathbf{n}$ & $\%$ & $\mathbf{n}$ & $\%$ \\
\hline \multirow[t]{3}{*}{2011} & \multirow{3}{*}{1676} & Passed & 1505 & 87.8 & 92 & 5.5 & 20 & 1.2 \\
\hline & & Failed & 171 & 10.2 & 29 & 1.7 & 9 & 0.5 \\
\hline & & Lost to follow-up & 0 & 0 & 50 & 2.9 & 0 & 0 \\
\hline \multirow[t]{3}{*}{2012} & \multirow{3}{*}{4269} & Passed & 3566 & 83.5 & 263 & 6.1 & 226 & 5.3 \\
\hline & & Failed & 703 & 16.4 & 244 & 5.7 & 18 & 0.4 \\
\hline & & Lost to follow-up & 0 & 0 & 196 & 4.6 & 0 & 0 \\
\hline \multirow[t]{3}{*}{2013} & \multirow{3}{*}{2421} & Passed & 2130 & 88 & 89 & 3.6 & 101 & 4.1 \\
\hline & & Failed & 291 & 12 & 152 & 6.2 & 29 & 1.2 \\
\hline & & Lost to follow-up & 0 & 0 & 50 & 2 & 22 & 0.9 \\
\hline \multirow[t]{3}{*}{2014} & \multirow{3}{*}{2010} & Passed & 1410 & 70.1 & 192 & 9.5 & 329 & 16.3 \\
\hline & & Failed & 600 & 29.8 & 358 & 17.8 & 14 & 0.7 \\
\hline & & Lost to follow-up & 0 & 0 & 50 & 2.9 & 15 & 0.7 \\
\hline \multirow[t]{3}{*}{2015} & \multirow{3}{*}{2408} & Passed & 1706 & 70.8 & 194 & 8.0 & 301 & 12.5 \\
\hline & & Failed & 702 & 29.1 & 408 & 17 & 11 & 0.4 \\
\hline & & Lost to follow-up & 0 & 0 & 100 & 4.1 & 96 & 3.9 \\
\hline \multirow{3}{*}{$\begin{array}{l}2016 \\
\text { (April) }\end{array}$} & \multirow{3}{*}{909} & Passed & 670 & 73.7 & 33 & 3.6 & 177 & 19.4 \\
\hline & & Failed & 239 & 26.2 & 186 & 20.4 & 0 & 0 \\
\hline & & Lost to follow-up & 0 & 0 & 20 & 2.2 & 9 & 1.0 \\
\hline
\end{tabular}




\section{Discussion}

Congenital hearing loss is more frequent compared to other diseases or syndromes being scanned. As a part of the newborn screening program worldwide, phenylketonuria is seen at a ratio of $0.03 / 1000$, hypothyroidism is seen at a ratio of $0.28 / 1000$, galactosemia is seen at a ratio of $0.02 / 1000$ and Down syndrome is seen at a ratio of $1 / 700$ (13). The incidence of hearing loss in newborns is about $1-3 / 1000$ in the normal population and is about $2-4 / 1000$ in the risky infants (14). These rates show that late diagnosis of hearing loss is unacceptable.

Screening tests for hearing loss are commonly performed only in high-risk groups in the first years of life. None of parents and doctors is successful enough to recognize infants with severe hearing loss in the first years of life. Although families assume that they may notice hearing loss in their children in 2.5-3 months of age, the screening programs have shown that families are aware of their child's severe hearing loss in two-three years and are aware of their child's moderate and mild hearing loss in four-five years and, sometimes even during the school years. Children develop a very good adaptation to their hearing loss. They may react as if they hear warnings with tips gained from visual expressions such as facial expressions, hand and body movements of other people. Some children tend to turn back for the sound coming from the rear even though they do not hear. This welldeveloped adaptability causes delay in the age of diagnosis (15).

Therefore, screening is the only valid method for early detection of congenital hearing loss. The Joint Committee on Infant Hearing of the American Academy of Pediatrics suggests that hearing screening should be performed in all infants before the third month of life and appropriate interventions should be initiated before the sixth month (16). Newborn hearing screening has been performed in all newborns in the United States since 1999 (17). The newborn hearing screening program in our country was initiated under the leadership of Marmara University and
Hacettepe University. Marmara University and Hacettepe University started hearing screening for newborns born in their hospital in 1994 and 1998, respectively. In collaboration with the Prime Ministry Administration of Persons with Disabilities, hearing screening was performed in babies born in Ankara Zübeyde Hanım Maternity Hospital and, thus, the screening studies in our country were accelerated. The National Newborn Hearing Screening campaign has been initiated in our country since December 3, 2004. Newborn hearing screening has been performed in 906 screening centers in 81 provinces across Turkey by the end of 2013. Moreover, further evaluation of infants with suspected hearing loss is made in 49 referral centers (18).

Among the first studies made in accordance with the screening program, newborn hearing screening was performed in Hacettepe University Medical School between the years 1998 and 2003 by Bolat and Genç (19). In this study, 5485 babies have been screened and 11 babies (2/1000) were diagnosed with severe bilateral hearing loss. Çelik et al. (20) evaluated the results of hearing screening in 142128 babies born between the years 2005 and 2011 in Ankara Zekai Tahir Burak Training and Research Hospital which is one of the hospitals in which hearing screening was first made. From these patients, 26.690 underwent second otoacoustic emissions (OAE) test and 2412 patients underwent third OAE test and, consequently, 385 patients $(0.27 \%)$ were diagnosed with hearing loss. In a study made by Genç et al. (21) performed between the years 2000 and 2001, it was reported that $0.15 \%$ of 5832 babies and $0.03 \%$ of 12665 babies received the diagnosis of hearing loss in Zübeyde Hanım Maternity Hospital and Ankara Zekai Tahir Burak Training and Research Hospital, respectively. In a study made in 2010 by Övet et al. (22), 19464 babies were screened and $18(0.1 \%)$ were diagnosed with severe bilateral hearing loss. The rate of hearing loss of 0.94/1000 newborns born in our hospital was consistent with the national and international literature $(1,23,24)$. In the literature, the

\begin{tabular}{|l|l|l|l|l|}
\hline \multicolumn{6}{|l|}{ Table 2. The status of newborns referred to a tertiary hospital by years. } \\
\hline Year & $\begin{array}{l}\text { Patients who have } \\
\text { referred to }\end{array}$ & $\begin{array}{l}\text { Patients who have passed the } \\
\text { ABR screening test }\end{array}$ & $\begin{array}{l}\text { Patients who have failed the ABR } \\
\text { screening test }\end{array}$ & Lost to follow-up \\
\hline $\mathbf{2 0 1 1}$ & 9 & 6 & 2 & 1 \\
\hline $\mathbf{2 0 1 2}$ & 18 & 14 & 3 & 1 \\
\hline $\mathbf{2 0 1 3}$ & 29 & 24 & 3 & 2 \\
\hline $\mathbf{2 0 1 4}$ & 14 & 11 & 2 & 1 \\
\hline $\mathbf{2 0 1 5}$ & 11 & 7 & 3 & 1 \\
\hline $\mathbf{2 0 1 6}$ & 0 & - & - & - \\
\hline Total & $\mathbf{8 1}$ & $\mathbf{6 2}$ & $\mathbf{1 3}$ & $\mathbf{6}$ \\
\hline ABR: Auditory brainstem response & & & \\
\hline
\end{tabular}


incidence of bilateral hearing loss and unilateral hearing loss has been reported to be between 0.13 and $0.60 \%$ and 0.17 and $0.38 \%$, respectively $(2,23,25-27)$. In our study, the incidence of bilateral hearing loss and unilateral hearing loss was $0.06 \%$ and $0.02 \%$, respectively.

The most extensive research on hearing impairment in our country was made by the Prime Ministry Administration of Persons with Disabilities in 2002 (28). The prevalence of hearing impairment in Turkey was found to be $0.37 \%$. This rate increases to $0.45 \%$ in rural areas. The prevalence of hearing loss is highest in the Black Sea region (0.45\%). According to this study (28), there are 63173 children with hearing loss in individuals aged 0-19 years in our country. It is estimated that only $20.8 \%$ of these children use hearing aids. According to the data of the same study, each year, about 2600-3900 babies are born with hearing impairment and $250-500$ children are added to this number in the first 10 years of life. $7.77 \%$ of all people with hearing impairment in our country work in a job and $5.3 \%$ of them look for a job and, the remaining $87 \%$ do not work (28).

Early diagnosis and treatment of hearing loss affect positively the child's emotional, social and academic level as well as language development (4). The lowest frequency of sound the human ear can hear is 10-15 decibels $(\mathrm{dB})$. Hearing loss is classified as mild (26-40 dB), moderate (41$55 \mathrm{~dB})$, moderate to severe (56-70 dB), severe (71-90 dB), and very severe (above $91 \mathrm{~dB}$ ). A congenital hearing loss in a range of approximately $500-4000 \mathrm{~Hz}$ and are over $30 \mathrm{~dB}$ would affect normal speech and language development of the baby (29).

\section{Table 3. General appearance of the newborns who were referred} to the tertiary care center

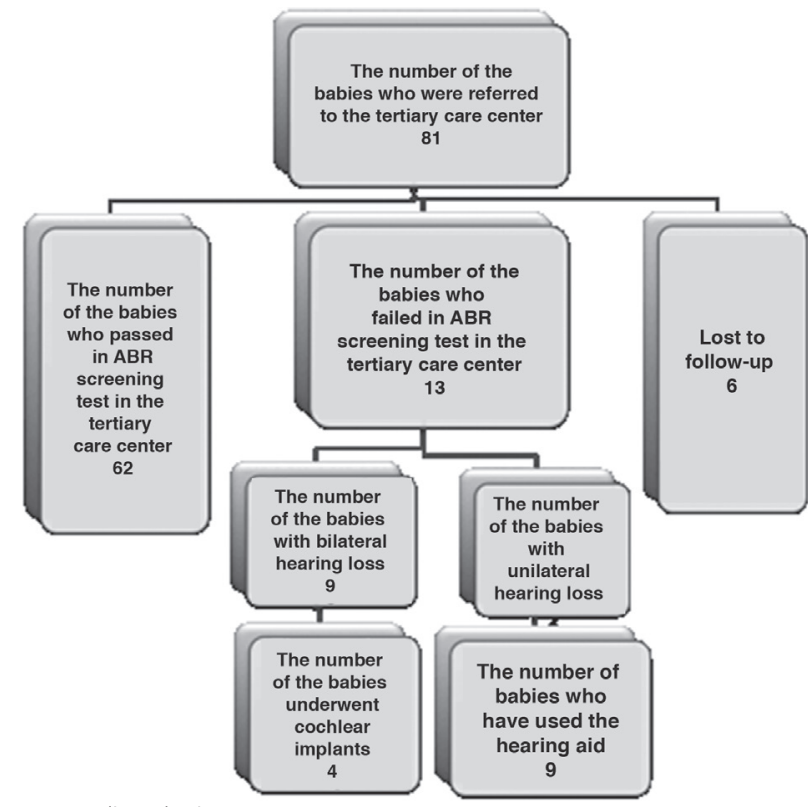

ABR: Auditory brainstem response
Hearing screening in newborns aims to diagnose early, cheaply and exactly babies with severe and very severe hearing loss as much as possible. The EOAE and the ABR measurements based on electrophysiology are widely used alone or in combination in newborn hearing screening $(30,31)$. Both methods do not require intervention and are applied quickly and easily and do not need specially trained personnel. The OAE measurement which was defined for the first time in 1978 by Kemp is currently the most promising newborn hearing screening method (32). The most commonly used OAEs as hearing test are TEOAE and DPOAE. The OAE tests are based on measurement of emissions via a microphone placed in the external ear canal and the waves generated by the cochlea against the sound stimulus are saved. The TEOAE measurement, which is an objective, fast, inexpensive and non-invasive method, is widely used in a reliable manner, especially in newborn hearing screening programs $(1,2)$. The presence of this response in both ears shows that the outer hairy cells have normal function, and hearing loss is not above $30 \mathrm{~dB}$ (33). Although OAE test is faster compared to ABR test, the test may give false results in case that there is debris in the external ear, the ambient noise is above the threshold or there are pathologies such as middle ear fluid considered as normal within the first $12-24$ hours of life $(34,35)$. The noise level of the room where the hearing screening is performed is important for the measurement reliability. The TEOAE hearing screening in our hospital is performed in a private room in the newborn hearing screening unit. Moreover, it cannot detect the retro-cochlear pathologies and hearing loss less than $35 \mathrm{~dB}$ (36). ABR screening is an electrophysiological measurement which evaluates hearing function from the eighth nerve to the brain stem. The responses in the first $10-20 \mathrm{~m} / \mathrm{sc}$ of the electrical potentials, which are generated on the auditory pathways and the brainstem by intermittent stimuli on the ABR test, are measured by surface electrodes placed on the mastoid and the neck (30). In recent years, ABR is used alone in newborn hearing screening (37). ABR has disadvantages such as that it requires placement of electrode, takes longer time and measurement is performed while the baby sleeps.

Newborn hearing screening is performed for early, cheap and exact diagnosis of hearing loss in infants and for planning appropriate interventions as much as possible. The goal of an effective screening program is to screen a minimum of $95 \%$ of infants and it should aim $100 \%$ of infants. The false positive rate should be $<3 \%$, referral rate should be $<4 \%$ and false negative rate should be 0 (38). All the babies born in our hospital underwent the first OAE test before discharge (100\%). In our study, newborns, who have failed the second TEOAE test and then the ABR test $(0.6 \%)$, were referred to a tertiary care center. 
Hearing loss may occur in three different periods of life including the prenatal, perinatal and postnatal periods. The prenatal period includes the risk factors for hearing loss that may occur during the mother's pregnancy. These may be considered as genetic causes, use of ototoxic medications, and exposure to radiation, congenital infections (TORCH), trauma, and certain systemic diseases. In the perinatal period, babies with low birth weight (less than 1500 grams), blood incompatibility, intensive care unit stay, asphyxia, head trauma during birth (vacuum, forceps, etc.), blood exchange and infections may be considered the possible risk factors. In the postnatal period, infections, convulsions, use of ototoxic medications, head trauma, genetic disorders, craniofacial anomalies, exposure to high violence and idiopathic reasons may be considered possible risk factors $(39,40)$. Even if they pass on the newborn hearing screening, it is important that children with a family history of hearing loss should be monitored in certain periods (41). In our study, all 13 babies who were referred to the tertiary care center had a specific risk factor.

According to the Joint Committee on Infant Hearing, it is stated that these protocols give very good results (42). Newborns with hearing loss should be recognized by performing hearing screening for newborns and it is important to ensure the normal development by directing them to early treatment, to appropriate amplification or cochlear implantation if necessary. Cochlear implants are used in addition to conventional hearing aids in patients with hearing loss. A cochlear implant is an electronic hearing device designed for patients with severe and very severe hearing loss who do not benefit from hearing aids. In a study by Yorgancilar et al. (43), it was found that cochlear implantation was an effective treatment method. In children receiving necessary intervention by earlier than six months of life, the results within the normal range have been obtained on expressive language tests applied in three years (44). In our study, four patients underwent cochlear implant and the decision for surgery was made for nine patients.

The purpose of newborn hearing screening program is to detect infants with hearing loss in the first three months of life and to make the necessary interventions before six months and to start both instrumentation and educational study. In the past, however, both families and pediatricians did not suspect hearing loss before the age of two-three and these children's speech and language skills were underdeveloped as irreversible. Child health specialists and neonatal intensive care physicians also have a key role in newborn hearing screening. To start treatment without delay, child health specialists, family physicians, nurses, midwives and community should be informed about the importance of hearing screening.

\section{Conclusion}

Babies suspected to have hearing loss have been directed to relevant healthcare centers in order to start treatment, rehabilitation and training processes; and for the purpose of follow-up and make a definitive diagnosis of the hearing loss. The definitive diagnosis in babies who have failed hearing screening should be made with more advanced methods. Speech and language abilities and emotional, social and cognitive development of children may successfully be improved with early diagnosis, treatment and rehabilitation of congenital hearing loss. Newborn hearing screening that is very important for early diagnosis must be performed in all maternity hospitals and for every newborn. In addition, the number of audiologists and third-level diagnostic and treatment centers should be increased.

\section{Ethics}

Ethics Committee Approval: Ethics committee approval was received for this study from the Local Ethics Committee (approve number: CMRC-2016/244).

Peer-review: Internally peer-reviewed.

\section{Authorship Contributions}

Concept: A.Y. Design: U.G. Data Collection or Processing: S.K. Analysis or Interpretation: F.H.Y. Literature Search: A.Y. Writing: A.Y.

Conflict of Interest: No conflict of interest was declared by the authors.

Financial Disclosure: The authors declared that this study has received no financial support.

\section{References}

1. Hahn M, Lamprecht-Dinnesen A, Heinecke A, et al. Hearing screening in healthy newborns: feasibility of different methods with regard to test time. Int J Pediatr Otorhinolaryngol 1999;51:83-9.

2. Thompson DC, McPhillips H, Davis RL, Lieu TL, Homer CJ, Helfand M. Universal newborn hearing screening: summary of evidence. JAMA 2001;286:2000-10.

3. American Academy of Pediatrics, Joint Committee on Infant Hearing. Year 2007 position statement: Principles and guidelines for early hearing detection and intervention programs. Pediatrics 2007;120:898-921.

4. Kennedy CR, McCann DC, Campbell MJ, et al. Language ability after early detection of permanent childhood hearing impairment. N Engl J Med 2006;354:2131-41.

5. Hepper PG, Shahidullah BS. Development of fetal hearing. Arch Dis Child 1994;71:81-7.

6. Patel H, Feldman $\mathrm{M}$; Universal newborn hearing screening, Canadian Paediatric Society, Community Paediatrics 
Committee, Reference No. CP 2011-02, Pediatr Child Health 2011;16:301-5.

7. Giordano T, Marchegiani AM, Germiller JA. Children With Sensorineural Hearing Loss and Referral to Early Intervention. ORL Head Neck Nurs 2015;33:10-4.

8. Kennedy CR. Neonatal screening for hearing impairment. Arch Dis Child 2000;83:377-82.

9. Center for disease control and prevention (CDC). Serious hearing impairment among children aged 3-10 years. Atlanta, Georgia, 1991-1993. MMWR Morb Mortal Wkly Rep 1997;46:1073-6.

10. Prieve BA, Stevens F. The New York State newborn hearing screening demonstration project, introduction and overview. Ear Hear 2000;21:85-91.

11. Nekahm D, Weichbold V, Welzl-Mueller K, Hirst-Stadlmann A. Improvement in early detection of congenital hearing impairment due to universal newborn hearing screening. Int J Pediatr Otorhinolaryngol 2001;59:23-8.

12. Bluestone CD, Stool SE, Kenna MA(eds): Pediatric Otolaryngology (ed 3). Philadelphia, W.B. Saunders, 1996.

13. Finitzo T, Crumley WG. The role of the pediatrician in hearing loss. From detection to connection. Pediatr Clin North Am 1999;46:15-34.

14. Vohr BR, Carty LM, Moore PE, Letourneau K. The Rhode Island Hearing Assessment Program experience with state wide hearing screening (1993-1996). J Pediatr 1998;133:353-7.

15. Anne M Delaney, Arlen D Meyers. Newborn Hearing Screening - Diseases\&Conditions. http://emedicine.medscape.com/ article/836646-overview.

16. JCIH. Year 2000 position statement: principles and guidelines for early hearing detection and intervention programs. Joint Commitee on Infant Hearing, American Academy of Audiology, American Academy of Pediatrics, American Speech-Language-Hearing Association, and Directors of Speech and Hearing Programs in State Health and Welfare Agencies. Pediatrics 2000;106:798-817.

17. JCIH Year 2007 Position Statement: Principles and Guidelines for Early Hearing Detection and Intervention Programs. Pediatrics 2007;120:4:898-920.

18. Hacettepe Üniversitesi Yenidoğan İşitme Taraması ve Erken Tanı Uygulama ve Araştırma Merkezi. http://www.yitmer. hacettepe.edu.tr/tarihce.shtml

19. Bolat H, Genç GA. Türkiye Ulusal Yenidoğan İşitme Tarama Programı: Tarihçesi ve Prensipleri. Turkiye Klinikleri J E.N.T. Special Topics 2012;5:11-4.

20. Çelik IH, Canpolat FE, Demirel G ve ark. Isşitme Tarama Sonuçlarının Değerlendirilmesi. Türk Ped Arş 2014;49:138-41.

21. Genç GA, Ertürk BB, Belgin E. Yenidoğan işitme taraması: başlangıçtan günümüze. Çocuk Sağlığı ve Hastalıkları Dergisi 2005;48:109-18.

22. Övet $G$, Işık Balcı $Y$, Canural R, ve ark. Yenidoğan İşitme Tarama Sonuçlarımız. Adnan Menderes Üniversitesi Tıp Fakültesi Dergisi 2010;11:27-9.
23. Lin CY, Huang CY, Lin CY, Lin YH, Wu JL. Community based newborn hearing screening program in Taiwan. Int J Pediatr Otorhinolaryngol 2004;68:185-9.

24. Rouev P, Mumdzhiev H, Spiridonova J, Dimov P. Universal newborn hearing screening program in Bulgaria. Int J Pediatr Otorhinolaryngol 2004;68:805-10.

25. Fujikawa S, Yoshinaga-Itano C. Current status of universal newborn hearing screening. Curr Opin Otolaryngol Head Neck Surg 2000;8:404-8.

26. Finitzo T, Albright $\mathrm{K}, \mathrm{O}^{\prime} \mathrm{Neal} J$. The newborn with hearing loss: detection in the nursery. Pediatrics 1998;102:1452-60.

27. Cox LC, Toro MR. Evolution of a universal infant hearing screening program in an innercity hospital. Int J Pediatr Otorhinolaryngol 2001;59:99-104.

28. Kırman A, Yıldırım Sarı H. İşitme Engelli Çocuk ve Adölesanların Sağlık Durumları. Güncel Pediatri 2011;9:85-92.

29. Jakubikova J, Kabatova Z, Zavodna M. Identification of hearing loss in newborns by transient otoacoustic emissions. Int J Pediatr Otorhinolaryngol 2003;67:15-8.

30. Thornton AR, Kimm L, Kennedy CR. Methodological factors involved in neonatal screening using transient-evoked oto acustic emissions and automated auditory brainstem response testing. Hear Res 2003;182:65-76.

31. Gabbard SA, Northern JL, Yoshinaga-Itano C. Hearing screening in newborns under 24 hours of age. Semin Hera 1999;20:291-305.

32. Kemp DT. Stimulated acoustic emissions form the human auditory system. J Acoust Soc Am 1978;64:1386-91.

33. Paludetti G, Ottaviani F, Fetoni AR, Zuppa AA, Tortorolo G. Transient evoked otoacoustic emissions (TEOAEs) in newborns: normative data. Int J Pediatr Otorhinolaryngol 1999;47:235-41.

34. Joint Committee on Infant Hearing. American Academy of Pediatrics Position Statement. Pediatrics 1982;70:496-7.

35. Yoon PJ, Price M, Gallagher K, Fleisher BE, Messner AH. The need for long-termaudilogic follow-up of neonatal intensive care unit graduates. Int J Pediatr Otorhinolaryngol 2003;67:353-7.

36. Geal-Dor M, Adelman C, Levi H, Zentner G, Stein-Zamir C. Comparison of two hearing screening programs in the same population: oto-acoustic emissions (OAE) screening in newborns and behavioral screening when infants. Int J Pediatr Otorhinolaryngol 2010;74:1351-5.

37. Iwasaki S, Hayashi Y, Seki A, et al. A model of two stage newborn hearing screening with automated auditory brainstem response. Int J Pediatr Otorhinolaryngol 2003;67:1099-104.

38. Erenberg A, Lemons J, Sia C, et al. Newborn and infant hearing loss: detection and intervention. American Academy 
of Pediatrics. Task Force on. Newborn and Infant Hearing, 1998-1999. Pediatrics 1999;103:527-30. http://pediatrics. aappublications.org/content/pediatrics/103/2/527.full.pdf

39. Bielecki I, Horbulewicz A, Wolan T. Risk factors associated with hearing loss in infants: An analysis of 5282 referred neonates. Int J Pediatr Otorhinolaryngol 2011;75:925-30.

40. Reşorlu M, Meydan R. Koklear implantasyon adayı hastaların yüksek rezolüsyonlu bilgisayarlı tomografi ve manyetik rezonans inceleme sonuçlarının değerlendirilmesi. Dicle Med J 2012;3:392-7.
41. Driscoll C, Beswick R, Doherty E, D'Silva R, Cross A. The validity of family history as a risk factor in pediatric hearing loss. Int J Pediatr Otorhinolaryngol 2015;79:654-9.

42. Korres S, Nikolopoulos TP, Peraki EE et al. Outcomes and efficacy of newborn hearing screening: strengths and weaknesses (successor failure?). Laryngoscope 2008;118:1253-6.

43. Yorgancılar E, Yıldırım M, Gün R, et al. Koklear implantasyon cerrahisi uygulanan 36 hastanın analizi. Dicle Med J 2012;39:262-8.

44. Downs MP. Universal newborn hearing screening-The Colorado story. Int J Pediatr Otorhinolaryngol.1995;32:257-9. 